\title{
ANAEROBIC DIGESTION OF SPECIFIC BIODEGRADABLE WASTE AND FINAL DISPOSAL
}

\author{
Sanja Kalambura, Tajana Krička, Darko Kiš, Sonja Marić, Sunčica Guberac, Dražan Kozak, Antun Stoić, \\ Aleksandar Racz
}

Original scientific paper

The present paper investigates the effectiveness of different levels of applied digested residue obtained after anaerobic digestion (AD) of meat-bone meal (MBM) on the morphologic and mineral characteristics of corn. The experiment was conducted in duration of two years and consisted of eight treatments: control (without any fertilizer); mineral fertilization only; treatments with minimum, medium and maximum dosage of digested MBM; fertilization of minimum, medium and maximum dosages of $\mathrm{AD}$ residue combined with mineral fertilizer. By combination of treatments with mineral fertilizer and different rates of $\mathrm{AD}$ residue, plants increased mass yield, they were larger and had more leaves. Content of mineral substances was within average values, both in plant material and in kernel, and variations in values were conditioned by total mass and ion interactions. MBM after AD treatment is possible to be applied as organic fertilizer. It has higher nutritive value and, as such, is suitable for treatment of agricultural plants, especially in crop production.

Keywords: anaerobic digestion; corn; fertilization; meat bone meal

\section{Anaerobna digestija specifičnog biorazgradivog otpada i konačno zbrinjavanje}

Izvorni znanstveni članka Ovaj rad istražuje učinkovitost primjene različitih razina digestiranog ostatka, dobivenog nakon anaerobne digestije (AD) mesno-koštanog brašna (MKB), na morfološka i mineralna svojstva kukuruza. Istraživanje je provedeno u trajanju od dvije godine, a sastojalo se od osam tretmana: kontrola (bez gnojiva); samo mineralna gnojidba; tretmani s najmanjom, srednjom i maksimalnom dozom digestiranog MKB-a; gnojidba minimalnom, srednjom i maksimalnom dozom digestiranog ostatka u kombinaciji s mineralnim gnojivom. Kombinacija tretmana s mineralnim gnojivom i različitom dozom ostatka anaerobne digestije, povećala je prinos mase biljke, bile su veće i imale više lišća. Sadržaj mineralnih tvari bio je prosječne vrijednosti, kako u biljnom materijalu tako i u jezgri. Varijacije vrijednosti uvjetovane su ukupnom masom i ionskim interakcijama. MKB nakon tretmana AD moguće je primijeniti kao organsko gnojivo. Ima veće hranjive vrijednosti i, kao takvo, prikladno je za tretiranje poljoprivrednih biljaka, posebno u ratarstvu.

Ključne riječi: anaerobna digestija; gnojidba; kukuruz; mesno-koštano brašno

\section{Introduction}

The production of organic waste can be considered as inherent to highly developed societies. Organic waste is generated from agricultural production, food processing and beverage production or even from domestic waste [1]. Wastes and residues resulting from diverse agricultural activities, such as planting and harvesting of row, field and tree and vine crops, milk production, production of animals for slaughter, and operation of feedlots, are collectively called agricultural waste. Because of its specificity and continuous inflow from different industries and agricultural production, agricultural organic waste represents potential danger for environment and human health [2, 3]. In the meat industry, the slaughtering process is the largest contributor to liquid waste. Animal waste may be defined as carcasses or parts of animals, including products of animal origin not intended for direct human consumption. Furthermore, Salminen and Rintala [21] reported that because of legal restrictions, rising treatment costs and environmentally conscious consumers, the treatment of some solid residues and wastes, and particularly residues from wastewater treatment processes, emerged as a major concern in the meat industries. Meat-bone meal (MBM) is a dried product of the rendering industry [4]. It does not contain horn, hairs, hide trimmings, manure, stomach contents, added blood meal or poultry by-products. It typically contains about $50 \%$ protein, $35 \%$ ash, $8 \div 12 \%$ fat and $4 \div 7 \%$ moisture [4]. The procedure of making MBM is as follows: safe animal wastes (meat and bones) coming from slaughterhouse waste are mixed, crushed and cooked together. After the cooking process, tallow is extracted and the remaining residue, known as MBM or animal flour, is sterilized before being safely disposed off
[5]. MBM was widely recommended and used in animal nutrition as a protein source in place of proteinaceous feeds because of its content of available essential amino acids, minerals and vitamin B12 in monogastric nutrition and rumen escape proteins in ruminant nutrition $[6,3]$. But, as a result of the recent bovine spongiform encephalopathy (BSE) crisis in the European beef industry, the use of animal by-product is now strictly controlled. Since November 2000, MBM production can no longer be used to feed cattle, but can be incorporated in food for pigs, poultry, fish or pet food $[7,3]$.

In the EU, there is regulation: Regulation (EC) No. 1069/2009 and of the European Parliament and of the Council of 21 October 2009. That regulation lays down the health rules concerning animal by-products not intended for human consumption and explains the conditions for disinfection and control as to ensure pathogen removal in most of the meat wastes to be biologically degraded. They also consider incineration as a sanation. The safety of food products is one of the priorities in many countries in the world. In the European Union a comprehensive food safety strategy, called "from farm to fork", is implemented. Its operation covers food safety, animal health and welfare and plant health (Regulation (EC) No 178/2002). This is connected with the legislation, good hygiene practices during production, and continuous monitoring of raw materials and products. Appropriate manufacturing technology, including aspects of mixing processes associated with accompanying processes, as homogenization and segregation, and management of their safety and quality are important for every consumer. Sometimes, as a result of segregation, the quality of the mixture is reduced during mixing. Particular difficulties arise when the components differ 
significantly in density and size and tend to occupy specific locations in the bed $[9,10,11]$.

\section{Materials and methods}

Meat bone meal (MBM). The sample of MBM obtained after incineration of $2^{\text {nd }}$ and $3^{\text {rd }}$ category of organic slaughterhouse waste was taken from one rendering house in Croatia and kept in deep freeze.

Digestion of MBM. At the Faculty of Agriculture University of Zagreb there is a lab-scale plant for biogas production, consisting of inox made thermostatic water bath of approx. $80 \mathrm{~L}$, electromagnetic stirrers and batch glass reactors, which fully simulate the conditions of industrial biogas production facilities. After completion of the chemical analysis, anaerobic digestion of MBM was started. The reactor of laboratory biogas plants was filled with MBM mixture, water and inoculum for triggering the digestion (fermentation) reaction, and the biogas production was set out. MBM was water-diluted in percentage of $5 \%$ of dry matter. Active slime taken from the waste water treatment facility was the inoculum used as MBM digestion agent. The anaerobic digestion process is conducted in mesophylic conditions, in terms of temperature $\left(35^{\circ} \mathrm{C}\right)$ and time period (30 days). The pressure in digestor ranged between $2,5 \mathrm{kPa}$ and $4 \mathrm{kPa}$.

Residue after anaerobic digestion of MBM. The chemical analyses of digested residue included the determination of chemical properties and presence of heavy metals in digested remains of MBM, soil on which the fertilizer test was conducted, whole plants and corn kernel, cultivated in fertilizer tests. The chemical analyses included the determination of: $\mathrm{pH}$, directly from sample on $\mathrm{pH}$-meter with combined electrode (DIN EN 12506:2003), electric conductivity (E.C.), by means of conductivity meter MA5964 with combined electrode design (ISO 7888:1985), total nitrogen, determined by Kjeldahl method (ISO 1871:1975), nitrate-N $\left(\mathrm{NO}_{3}{ }^{-}\right)$, determined by spectrophotometric method by means of yellow color complex by phenol-disulphonic acid (USDA-SCS-NSCS, 1992), ammonium-N $\left(\mathrm{NH}_{4}^{+}\right)$, determined by spectrophotometric method using Nessler's reagent based on Jackson method (1958), phosphorus, determined by the molybdate-blue spectrophotometric method, potassium and sodium determined by flame photometry, while all other microelements $(\mathrm{Ca}, \mathrm{Mg}, \mathrm{Mn}$, $\mathrm{Zn}, \mathrm{Cu}, \mathrm{Fe}, \mathrm{Pe}, \mathrm{Cd}$ ) are determined by use of atomic absorption spectrometry (AAS). During the vegetation period, plants are continuously supplied with water and soil nutrients. In addition, plants receive air and heat from soil. The combinations of all these functions of soil in plant cultivation make up its production capacity and fertility. However, soil fertility or capacity of soil to provide favourable conditions, in plant production, primarily depend on its physical and chemical traits. That is why it is necessary to have a good knowledge of soil and its characteristics in order to develop a successful plant production.

The corn growing tests were conducted in the SisakMoslavačka County. By soil types, this County belongs to the mountain agricultural region. In this sub-region, in addition to luvisol soil there is also district brown cambisol soil, relict red soil and gleyic soil. The share of luvisol soil is dominant. This type of soil has very good physical traits, its texture is clayey and relatively stable, and it has good water-holding capacity and is well drained. In order to gain insight in the soil characteristics, necessary laboratory tests were carried out on a research location.

In addition to the above-mentioned methods, the chemical analyses of soil were conducted in order to determine quality of soil before and after fertilization: $\mathrm{pH}$, soil reaction directly from sample on $\mathrm{pH}-$ meter with combined electrode design in soil water solution in 1:2,5 ratio (active acidity) and soil solution and IM KCI in 1:2,5 ratio (substitute acidity) (ISO 10390:2005), humus content, determined by Tjurin method, physiologically active phosphorous (P) and potassium (K) content determined by Enger-Reihm-Domingo method, content of physiologically active microelements and heavy metals is determined using AAS, in soil extract containing $0.1 \mathrm{M}$ $\mathrm{HCI}$, content of total microelements, determined by use of atomic-absorption spectrometer by pre-extraction of sample containing aqua regia.

In the fertilizer investigation which determined the influence of various fertilizer combinations on growth of corn plants, the following hybrids were used: Bc 462, Florencia and $\operatorname{Pr} 37 \mathrm{M}$ 34. The hybrid $\mathrm{Bc} 462$ is a Croatian hybrid, semi-flint, (Bc Institute, Zagreb, Croatia) while the hybrids Florencia (dent) and Pr $37 \mathrm{M}$ 34 (hard dent), are imported hybrids produced by Pioneer, USA. Before the research was started, the soil was analyzed in order to determine $\mathrm{pH}$, humus and nitrogen content as well as the content of phosphorus, potassium, calcium, and magnesium. Each plant pot contained $8 \mathrm{~kg}$ of soil. This analysis was carried out in order to determine initial status and quantity of basic nutrients in the soil in the plant pots as well as to determine the quantity of nutrients to be added in two top dressing applications. The quantity of nutrients added to the soil was also determined on the basis of corn's needs for nutrients, which are as follows: $200 \mathrm{~kg} / \mathrm{ha} \mathrm{N}, 100 \mathrm{~kg} / \mathrm{ha} \mathrm{P}$ and $240 \mathrm{~kg} / \mathrm{ha} \mathrm{K}$. Before planting kernels in the plant pots soil was added, in the combination B 1,31 $\mathrm{g}$ of MAP and 3,20 $\mathrm{g} \mathrm{K}_{2} \mathrm{~S}_{4}$. In the combinations $\mathrm{F}, \mathrm{G}$, and $\mathrm{H}, 0,66 \mathrm{~g}$ of MAP and 1,60 $\mathrm{g}$ of $\mathrm{K}_{2} \mathrm{SO}_{4}$ were added. Before sowing, organic fertilizer was analyzed. The corn kernel was sown in pots on 25 April 2007 and on 25 April 2008. In each pot, planted corn kernels were sown manually in three repetitions, on approximately equal distance, in order to determine the impact of digested MBM fertilization, as organic fertilizer, on growth of corn plant. With the aim of determining these impacts, the following combinations for each hybrid were made: A - control ( without fertilizer application), B - pots in which only mineral fertilization was applied, $\mathrm{C}$ - pots in which only organic fertilization was applied, minimum dose $(5,76 \mathrm{~g}$ by pot), D - pots in which only organic fertilization was applied, medium dose (11,52 g by pot), E - pots in which only organic fertilization was applied, maximum dose $(23,00 \mathrm{~g}$ by pot $)$, $\mathrm{F}$ - pots in which combined fertilization was applied, as follows: minimum dose of organic fertilizers plus one half of mineral only fertilizer, $\mathrm{G}$ - pots in which combined fertilization was applied, as follows: medium dose of organic fertilizer plus one half of mineral only fertilizer, $\mathrm{H}$ - pots in which combined fertilization was applied, as 
follows: maximum dose of organic fertilizer plus one half of mineral only fertilizer.

Total of 72 pots were used in the fertilizer test. In the first and second top dressing applications urea wad was added $(46 \% \mathrm{~N})$. In the combination $\mathrm{B}, 1,4$ grams of urea was added while in the combinations F, G and $\mathrm{H}$ urea was added in a quantity of 1,12 grams. The mentioned urea quantities applied in the first and second top dressing applications were added in 2006 and 2007 as well. All combinations were applied on all hybrids, and it should be noted that each combination had three plant pots (repetitions). The first investigation of plant pots was carried out 19 days after sowing. Number of leaves by plant and number of plants by plant pot were recorded at this point. Twelve days after the first investigation of plant pots, the first top dressing was applied in the combinations B, F, G, and $\mathrm{H}$. The first samples of plants from the plant pots were taken 12 days after the top dressing application, and the following parameters were analyzed: number of leaves, length and mass, dry matter and chemical contents in the plant (stem and leaves). Twenty-three days after the first top dressing application, the second application was performed on the same combinations as in the first one, i.e., combinations B, F, $\mathrm{G}$, and $\mathrm{H}$. Twenty-four days after taking the first plant samples, the second plant samples were taken from the plant pots. Number of leaves, length and mass, dry matter and plant's chemical contents (stem and leaves). The last samples of plant material and kernel were taken on 26 October each year, and the following parameters were determined: plant length and mass, share of kernel in corncob, dry matter and chemical contents in kernel.

Statistical analysis. All data were analysed according to GLM procedure in the SAS system package version 9.1 (SAS Institute 2000). Since the design of the experiment was not specifically defined (the allocation was made on absolutely random basis with various numbers of observations), the average values for each investigated factor were calculated and interaction was included in the relevant analysis. All measurements were carried out in triplicates. Data were expressed as mean \pm SE using ANOVA, and if justified by the statistical probability $(P<0,05)$, subjected to Duncan's new multiple range test. Differences were considered statistically significant if $P<0,05$.

\section{Results and discussion}

Chemical composition of MBM samples before anaerobic digestion was determined and is shown in Tab. 1.

Table 1 Composition of MBM used in the investigation

\begin{tabular}{|c|c|}
\hline MBM content & $\%$ \\
\hline Water & $1,82 \pm 0,09$ \\
\hline Ash & $21,78 \pm 1,46$ \\
\hline Protein & $56,83 \pm 3,78$ \\
\hline Fat & $12.17 \pm 1.24$ \\
\hline
\end{tabular}

Tab. 2 describes the results of chemical analysis of digested residue used in the fertilizer test. As to determine the quantities of fertilizers for treatment of corn growing, the soil was analysed, and the results are given in Tab. 3.

Table 2 Mean values of chemical analyses results of digested residue

\begin{tabular}{|c|c|c|c|}
\hline Nr. & \multicolumn{2}{|r|}{ Chemical analysis } & Digested MBM \\
\hline 1. & \multicolumn{2}{|r|}{$\mathrm{pH}$ directly } & $6,24 \pm 0,05$ \\
\hline 2. & \multicolumn{2}{|r|}{ E.C. $\mathrm{mS} / \mathrm{cm}$} & $21,59 \pm 3,40$ \\
\hline 3. & \multicolumn{2}{|r|}{$\%\left(\mathrm{DM} 105^{\circ} \mathrm{C}\right)$} & $4,56 \pm 1,94$ \\
\hline 5. & \multicolumn{2}{|c|}{$\%$ burning residue $\left(550^{\circ} \mathrm{C}\right)$} & $15,68 \pm 1,43$ \\
\hline 6. & \multicolumn{2}{|r|}{$\%$ burning loss } & $84,32 \pm 1,43$ \\
\hline 7. & \multicolumn{2}{|r|}{$\% \mathrm{C}$ organic } & $47,00 \pm 0,82$ \\
\hline 8. & \multirow{4}{*}{$\% \mathrm{~N}$} & In the natural sample & $0,60 \pm 0,25$ \\
\hline 9. & & Total in dry matter & $13,28 \pm 0,17$ \\
\hline 10. & & Other forms $\left(105^{\circ} \mathrm{C}\right)$ & $13,20 \pm 0,16$ \\
\hline 11. & & $\mathrm{NH}_{3}-\mathrm{N}$ & $0.08 \pm 0.01$ \\
\hline 12. & & $\% \mathrm{P}$ & $2,62 \pm 0,18$ \\
\hline 13. & & $\% \mathrm{~K}$ & $2,68 \pm 0,10$ \\
\hline 14. & & $\% \mathrm{Ca}$ & $5,14 \pm 0,11$ \\
\hline 15. & & $\% \mathrm{Mg}$ & $0,94 \pm 0,03$ \\
\hline 16. & & $\% \mathrm{Na}$ & $0,79 \pm 0,03$ \\
\hline 17. & & $\mathrm{mg} / \mathrm{kg} \mathrm{Mn}$ & $39,40 \pm 1,87$ \\
\hline 18. & & $\mathrm{mg} / \mathrm{kg} \mathrm{Zn}$ & $30,31 \pm 0,34$ \\
\hline 19. & & $\mathrm{mg} / \mathrm{kg} \mathrm{Cu}$ & $14,72 \pm 0,94$ \\
\hline 20. & & $\mathrm{mg} / \mathrm{kg} \mathrm{Fe}$ & $262,50 \pm 0,94$ \\
\hline 21. & & $\mathrm{mg} / \mathrm{kg} \mathrm{Pb}$ & $1,61 \pm 0,42$ \\
\hline 22. & & $\mathrm{mg} / \mathrm{kg} \mathrm{Cd}$ & $0,25 \pm 0,01$ \\
\hline
\end{tabular}

(Values are mean $\pm \mathrm{SE}$ )

Table 3 Soil chemical analyses in experiment

\begin{tabular}{|c|c|}
\hline Chemical analysis & Soil \\
\hline $\mathrm{pH}$ in $\mathrm{H}_{2} \mathrm{O}$ & $7,82 \pm 0,34$ \\
\hline $\mathrm{pH}$ in $1 \mathrm{M} \mathrm{KCl}$ & $7,10 \pm 0,52$ \\
\hline $\mathrm{Humus}(\%)$ & $2,38 \pm 0,16$ \\
\hline $\mathrm{N}(\%)$ & $0,12 \pm 0,02$ \\
\hline $\mathrm{P}(\mathrm{mg} / 100 \mathrm{~g}$ soil) & $41,00 \pm 3,28$ \\
\hline $\mathrm{K}(\mathrm{mg} / 100 \mathrm{~g}$ soil $)$ & $14,05 \pm 0,83$ \\
\hline $\mathrm{Mg}(\mathrm{mg} / 100 \mathrm{~g}$ soil $)$ & $34,00 \pm 1,78$ \\
\hline $\mathrm{Zn}(\mathrm{mg} / 100 \mathrm{~g}$ soil $)$ & $2,00 \pm 0,16$ \\
\hline $\mathrm{Mn}(\mathrm{mg} / 100 \mathrm{~g}$ soil $)$ & $130,00 \pm 14,28$ \\
\hline $\mathrm{Cu}(\mathrm{mg} / 100 \mathrm{~g}$ soil $)$ & $3,50 \pm 0,27$ \\
\hline $\mathrm{Fe}(\mathrm{mg} / 100 \mathrm{~g}$ soil $)$ & $212,00 \pm 5,78$ \\
\hline $\mathrm{Cd}(\mathrm{mg} / 100 \mathrm{~g}$ soil) & $0,25 \pm 0,02$ \\
\hline $\mathrm{Pb}(\mathrm{mg} / 100 \mathrm{~g}$ soil $)$ & $3,00 \pm 0,26$ \\
\hline
\end{tabular}

In early June (6 June) of both investigation years the first sampling of whole plant was carried out.

Tab. 4 below gives the data on leaves, plant length and mass.

After completion of preliminary researches, the investigations of anaerobic digestion of MBM commenced. The recovery of anaerobically digested residues for agriculture conserves and recycles nutrients and may reduce waste discharge and the use of chemical fertilizers, but the safety of the material must be carefully evaluated before use [18]. If the digested residue as a byproduct of biogas production is planned for application as a high quality plant fertilizer, it needs to satisfy the plants' requirements and must not contain an excessive quantity of heavy metals. Just before the fertilization, chemical analysis of digested residue obtained after biogas production of MBM was carried out. The analysis showed low content of dry matter $(4,56 \%)$ and high content of organic carbon $(47,00 \%)$. Such a low dry matter level is normal for digested residues obtained after biogas production. When diluted in water there are no 
chemical back reactions or gas discharges. Measurements of $\mathrm{pH}$ values established an almost neutral fertilizer's reaction $(\mathrm{pH}$ 6,24), which indicated that digestion performed well, i.e., evaporable fatty acids were not developed, and that there was no acidification of substrate, i.e., methane production was not halted. As for the quantity of basic biogenic nutrients, the examined samples were very rich in nitrogen $(13,20 \% \mathrm{~N})$, phosphorus $(2,62 \% \mathrm{P})$ and potassium $(2,68 \% \mathrm{~K})$. In order to determine the quality of digested residues, the contents of major biogenic elements was monitored in examined substrate, such as quantity of calcium, magnesium, and sodium. The examined digested residue contained moderate amounts of biogenic elements, which makes them suitable for fertilizer in agricultural production and it can be classified in category of liquefied organic fertilizers. In relation to farmyard manure, this fertilizer has higher amount of nitrogen, phosphorus, potassium, calcium, and magnesium and higher microelements content. Hence, this fertilizer can be used for fertilization but its application should be preceded by soil analysis and determination of needs of individual cultures for macro- and microelements. They are dark-coloured, still have offensive odour; when diluted in water there are no chemical back reaction or gas discharges. After being applied on agricultural arable areas they quickly become subject to further biological decomposition by aerobic bacteria up to the stage of plant nutrient, which in addition to plant nutrition has very favourable influence on microbiological activity in soil $[19,1,20,21,22]$.

Table 4 Average number of leaves, plant length and plant mass of investigated hybrids

\begin{tabular}{|c|c|c|c|c|}
\hline Parameter & $\begin{array}{l}\text { Number of } \\
\text { leaves }(\mathrm{g})\end{array}$ & $\begin{array}{l}\text { Plant length } \\
(\mathrm{cm})\end{array}$ & Plant mass & $\begin{array}{c}\text { Kernel share in } \\
\text { corncob mass }(\%)\end{array}$ \\
\hline Year $(Y)$ & NS & $*$ & $* * *$ & $* * *$ \\
\hline 1 & $9,57^{a} \pm 3,28$ & $117,53^{a} \pm 40,36$ & $83,57^{\mathrm{a}} \pm 43,83$ & $78,77^{\mathrm{a}} \pm 8,09$ \\
\hline 2 & $9,67^{\mathrm{a}} \pm 4,84$ & $98,05^{b} \pm 50,47$ & $37,10^{b} \pm 24,50$ & $82,65^{b} \pm 3,03$ \\
\hline Hybrid $(\mathrm{H})$ & NS & NS & NS & $* * *$ \\
\hline $\mathrm{Bc} 462$ & $10,02^{\mathrm{a}} \pm 4,30$ & $111,51^{\mathrm{a}} \pm 44,01$ & $60,84^{\mathrm{a}} \pm 42,85$ & $77,02^{b} \pm 8,58$ \\
\hline Pr37M34 & $9,49^{\mathrm{a}} \pm 3,92$ & $105,39^{a} \pm 44,47$ & $59,98^{\mathrm{a}} \pm 41,48$ & $81,68^{a} \pm 3,22$ \\
\hline Florencia & $9,35^{\mathrm{a}} \pm 4,19$ & $106,33^{\mathrm{a}} \pm 24,33$ & $60,20^{\mathrm{a}} \pm 43,66$ & $83,44^{\mathrm{a}} \pm 4,36$ \\
\hline Sampling (S) & $* * *$ & $* * *$ & $* * *$ & \\
\hline 1 & $6,32^{\mathrm{c}} \pm 0,92$ & $70,40^{\mathrm{c}} \pm 18,27$ & $31,23^{b} \pm 17,19$ & $81,21^{b} \pm 5,21$ \\
\hline 2 & $7,55^{b} \pm 1,42$ & $90,63^{b} \pm 30,21$ & $72,02^{\mathrm{a}} \pm 51,33$ & $80,82^{\mathrm{a}} \pm 6,01$ \\
\hline 3 & $14,99^{\mathrm{a}} \pm 1,98$ & $162,33^{a} \pm 24,23$ & $77,77^{\mathrm{a}} \pm 35,01$ & $80,72^{a} \pm 6,33$ \\
\hline Combination (C) & NS & $*$ & $* * *$ & $*$ \\
\hline $\mathrm{A}$ & $7,81^{\mathrm{a}} \pm 3,63$ & $81,29^{c} \pm 43,53$ & $25,07^{\mathrm{C}} \pm 17,40$ & $75,86^{\mathrm{b}} \pm 4,38$ \\
\hline $\mathrm{B}$ & $9,97^{\mathrm{a}} \pm 3,51$ & $125,44^{\mathrm{a}} \pm 47,17$ & $90,32^{\mathrm{a}} \pm 49,72$ & $84,09^{\mathrm{a}} \pm 3,49$ \\
\hline $\mathrm{C}$ & $9,13^{\mathrm{a}} \pm 4,24$ & $92,68^{\mathrm{bc}} \pm 39,94$ & $43,12^{\mathrm{bc}} \pm 32,05$ & $80,18^{\mathrm{ab}} \pm 4,71$ \\
\hline $\mathrm{D}$ & $9,66^{\mathrm{a}} \pm 4,62$ & $96,75^{\mathrm{abc}} \pm 38,17$ & $45,14^{\mathrm{bc}} \pm 30,84$ & $78,68^{\mathrm{ab}} \pm 5,46$ \\
\hline $\mathrm{E}$ & $9,68^{\mathrm{a}} \pm 4,39$ & $99,60^{\mathrm{abc}} \pm 39,88$ & $50,13^{\mathrm{b}} \pm 38,91$ & $79,40^{\mathrm{ab}} \pm 12,23$ \\
\hline $\mathrm{F}$ & $10,17^{\mathrm{a}} \pm 4,20$ & $121,09^{\mathrm{ab}} \pm 47,59$ & $75,20^{\mathrm{a}} \pm 39,64$ & $83,34^{\mathrm{a}} \pm 4,48$ \\
\hline G & $10,18^{\mathrm{a}} \pm 4,35$ & $124,04^{\mathrm{a}} \pm 50,44$ & $76,65^{\mathrm{a}} \pm 41,80$ & $82,04^{\mathrm{ab}} \pm 6,16$ \\
\hline $\mathrm{H}$ & $10,38^{\mathrm{a}} \pm 4,10$ & $121,41^{\mathrm{ab}} \pm 49,96$ & $77,11^{\mathrm{a}} \pm 42,06$ & $82,10^{\mathrm{ab}} \pm 5,13$ \\
\hline $\mathrm{Y} \times \mathrm{H}$ & $* * *$ & $* * *$ & $* * *$ & $* * *$ \\
\hline $\mathrm{Y} \times \mathrm{S}$ & $* * *$ & $* * *$ & $* * *$ & \\
\hline $\mathrm{Y} \times \mathrm{C}$ & $* * *$ & $* * *$ & $* * *$ & $* * *$ \\
\hline $\mathrm{H} \times \mathrm{S}$ & $* *$ & $* * *$ & $* * *$ & \\
\hline $\mathrm{H} \times \mathrm{C}$ & $* * *$ & $* * *$ & $* * *$ & $* * *$ \\
\hline $\mathrm{S} \times \mathrm{C}$ & $* * *$ & $* * *$ & $* * *$ & \\
\hline $\mathrm{Y} \times \mathrm{H} \times \mathrm{S}$ & $* * *$ & $* * *$ & $* * *$ & \\
\hline $\mathrm{Y} \times \mathrm{H} \times \mathrm{C}$ & $* * *$ & $* * *$ & $* * *$ & $* * *$ \\
\hline $\mathrm{Y} \times \mathrm{S} \times \mathrm{C}$ & $* * *$ & $* * *$ & $* * *$ & \\
\hline $\mathrm{H} \times \mathrm{S} \times \mathrm{C}$ & $* * *$ & $* * *$ & $* * *$ & \\
\hline $\mathrm{Y} \times \mathrm{H} \times \mathrm{S} \times \mathrm{C}$ & $* * *$ & $* * *$ & $* * *$ & \\
\hline
\end{tabular}

The use of digested residues is allowed on plant production surfaces, meadows and plain pastures where soils contain some of heavy metals and persistent organic harmful substances below $50 \%$ of marginal values set out under the Regulation on ecological production in plant cultivation and plant products in the Republic of Croatia [23]. Thus, according to the mentioned Regulation, the use of biological waste is possible providing that zinc content does not exceed $210 \mathrm{mg} / \mathrm{kg}$ in dry matter, copper $70 \mathrm{mg} / \mathrm{kg}$, lead $70 \mathrm{mg} / \mathrm{kg}$ and cadmium $0,7 \mathrm{mg} / \mathrm{kg}$ in dry matter. As shown in Tab. 2, these heavy metals analyzed in MBM digested residues were found in contents which are below prescribed limits, and they meet the requirements prescribed by the Croatian regulations (and the European Union regulations as well) and can be used in plant production.

Having in mind the complexity of application of digested MBM on agricultural surfaces, and in order to obtain accurate efficiency indicators of the above mentioned substrate, it was decided to examine, through a corn vegetation test, the nutritive value of this fertilizer and possible presence of heavy metals in the corn plant. 
In each plant pot the sowing was manually conducted at approximately equal distance with the aim to establish the influence of fertilization on com plant growth. Due to extreme sensitivity of these tests, the chemical analysis of soil included the tests for microelements and heavy metals as well. The contents of heavy metals in the examined samples is below maximum contents allowed (MAC), as set out under the Regulation on protection of agricultural land against harmful pollution agents [24].

Due to results in Tab. 2, the digested MBM residue can be applied in agricultural production, especially in corn production. However, no simple model can be used to define the nutrient additions needed for corn. Native soil fertility varies greatly from soil to soil, and the way these soils have been managed over the years greatly influences present soil fertility levels. Yield potential, soil type, and productions inputs must be considered when determining nutrient needs. On the basis of these investigations the data on soils and their traits are given below.

The share of luvisol soil used in this experiment is dominant. This type of soil has very good physical traits, its texture is clayey and relatively stable; it had good water-holding capacity and was well drained. Based on the results of chemical analysis, given in Table 1, it is evident that the soil on which the experiment was performed is slightly acid, moderate in organic substance (humus) and poor in nitrogen and potassium but rich in phosphorus and magnesium. In terms of the cam production needs, the soil is rich in physiologically active manganese, poor in zinc and copper and the amount of heavy metals is law. Anaerobic process of degradation of organic compounds, in a closed system such as biogas plant, suffers practically no nutrient loss. Degraded mineral compounds, especially nitrogen, remain in the digested residue and are "ready" for fertilization. As opposed to fertilization with non-fermented organic fertilizers, digested organic fertilizers have faster effect because of nutritive compounds which are already in mineral form and can be better utilized by plants.

Tab. 4 clearly shows that during the two-year investigation significant differences were determined in mass and length of the plant and in the share of kernel in corncob mass, while the differences in number of leaves exist but they are not significant. The highest values of the examined physical characteristics of corn were found in hybrid Bc 462, which had the largest number of leaves with the largest plant length and mass. If we look at the share of kernel in corncob mass we can establish that hybrid Florencia had a significantly higher value in the second year of the investigation.

In all examined hybrids, the combination A (plant pot without fertilizer application) had by far the lowest values of examined physical parameters of plants' length and mass, while the value of leaves number is the lowest. However, the difference from other parameters is not significant. The highest value of the leaves number was found in the fertilizing mix $\mathrm{H}$ (the largest dosage of organic fertilizer and half of quantity of total mineral fertilization) $(10,38)$, but this value is not significantly higher than the lowest values found in this two-year investigation. By far the highest values of the plant length $(125,44 \mathrm{~cm})$ and plant mass $(90,32 \mathrm{~g})$ were found in the fertilizing mix B, where mineral only fertilizer was applied. However, it is important to emphasize that the mass value $(124,04 \mathrm{~g})$ and length value $(76,65 \mathrm{~cm})$ for the fertilizing combination $G$ (medium dosage of organic fertilizer and half of mineral only fertilizer quantity) are only slightly lower than the highest values of the bestperforming fertilizing combination (B), but it should be noted that these differences are not significant. Like in all previous parameters, in determining the share of kernel in corncob mass, the fertilizing mix A was found to have the lowest value $(75,86 \%)$, while the fertilizing mix B proved to have the highest value of this parameter $(84,09 \%)$. However, all values in other combinations $(\mathrm{C}, \mathrm{D}, \mathrm{E}, \mathrm{F}, \mathrm{G} ; \mathrm{H})$ are not much lower than the highest values of the kernel-to-corncob mass found in the fertilizing combination B. Accordingly, it can be established that partly organic fertilization did not have very significant influence on diminishing plant mass and length, as well as on leaves number and on kernel-tocorncob mass when compared to mineral fertilization. Thus, partly organic fertilization can be fully applied in intensive fertilization of hybrid corn.

Plant analyses can be also useful in determining nutrient deficiencies. Deficiency symptoms, like plant analysis, have their greatest value for obvious growth problems. The two most distinctive deficiency symptoms on corn are those for nitrogen and potassium. For that reason, chemical analysis of plant material was carried out and content of nitrogen, phosphorus, potassium, calcium, and magnesium in all examined hybrids and fertilizing combinations was determined. The average data about the mentioned characteristics are given in Tab. 4. Dry matter content in plants of the investigated hybrid ranged from $37,55 \%$ in the fertilizing combination $\mathrm{A}$ to $39,13 \%$ in the combination F. However, these values do not differ significantly. Also, major differences were not found in the years of investigation either. This also applies to the investigated hybrids. The differences in dry matter were related to different sampling, which is a result of different maturation of the investigated hybrids. The shares of mineral matters, namely nitrogen, phosphorus, potassium, calcium, and magnesium levels in all investigated hybrids did not show significant differences, due to which it can be established that hybrid as such did not have any influence on examination of the mineral composition of the plant itself. Contrary to this, except for nitrogen, when shares of phosphorus, potassium, calcium and magnesium in different years of investigation are concerned the differences are significant and are due to agro-climatic condition during cultivation. In the first investigation year, higher values of potassium and magnesium were found, while in the second year phosphorus and calcium had higher values (Tab. 5).

There were no significant differences in nitrogen amounts between the investigation years, hybrids and fertilizing combinations. Nonetheless, the lowest nitrogen amount in dry matter of plant material was found in the combination A $(1,23 \%)$, and the highest one in the combination E (1,48\%). Significant differences were found only during different sampling, where the first sampling showed the highest amount of nitrogen in plant material $(1,99 \%)$. Contrary to nitrogen, phosphorus in 
the plants showed significantly different levels during the investigation. In the second year of investigation a somewhat higher amount of phosphorus was found $(0,94$ $\%$ ), as well as during the first sampling exercise where this value $(0,93 \%)$ was considerably higher than in the first sampling. The highest dry matter phosphorus in plant material was found in the combination $\mathrm{A}(1,20 \%)$, and the lowest dry matter phosphorus was found in the combination B $(0,76 \%)$.

Table 5 Mineral content in plant material (\% on dry matter basis)

\begin{tabular}{|c|c|c|c|c|c|c|}
\hline Parameter & $\%$ D.M. & $\mathrm{N}$ & $\mathrm{P}_{2} \mathrm{O}_{5}$ & $\mathrm{~K}_{2} \mathrm{O}$ & $\mathrm{Ca}$ & $\mathrm{Mg}$ \\
\hline Year $(Y)$ & NS & NS & $* * *$ & $* *$ & $* *$ & $* * *$ \\
\hline 1 & $39,90^{\mathrm{a}} \pm 36,31$ & $1,41^{\mathrm{a}} \pm 0,69$ & $0,69^{\mathrm{b}} \pm 0,19$ & $2,36^{\mathrm{a}} \pm 1,78$ & $0,51^{b} \pm 0,25$ & $0,36^{\mathrm{a}} \pm 1,75$ \\
\hline 2 & $36,96^{\mathrm{a}} \pm 33,88$ & $1,28^{\mathrm{a}} \pm 0,51$ & $0,94^{\mathrm{a}} \pm 0,28$ & $1,64^{b} \pm 1,05$ & $0,67^{\mathrm{a}} \pm 0,38$ & $0,27^{b} \pm 0,14$ \\
\hline Hybrid (H) & NS & NS & NS & NS & NS & NS \\
\hline $\mathrm{Bc} 462$ & $38,46^{\mathrm{a}} \pm 35,85$ & $1,34^{\mathrm{a}} \pm 0,44$ & $0,84^{\mathrm{a}} \pm 0,22$ & $2,23^{\mathrm{a}} \pm 1,61$ & $0,64^{\mathrm{a}} \pm 0,36$ & $0,31^{\mathrm{a}} \pm 0,17$ \\
\hline Pr37M34 & $39,21^{\mathrm{a}} \pm 35,34$ & $1,37^{\mathrm{a}} \pm 0,77$ & $0,82^{\mathrm{a}} \pm 0,29$ & $1,80^{\mathrm{a}} \pm 1,39$ & $0,61^{\mathrm{a}} \pm 0,30$ & $0,33^{\mathrm{a}} \pm 0,16$ \\
\hline Florencia & $37,64^{\mathrm{a}} \pm 34,60$ & $1,31^{\mathrm{a}} \pm 0,58$ & $0,81^{\mathrm{a}} \pm 0,28$ & $1,98^{\mathrm{a}} \pm 1,48$ & $0,53^{\mathrm{a}} \pm 0,32$ & $0,31^{\mathrm{a}} \pm 0,15$ \\
\hline Sampling (S) & $* * *$ & $* * *$ & $* * *$ & $* * *$ & $*$ & $* *$ \\
\hline 1 & $12,95^{\mathrm{a}} \pm 1,71$ & $1,99^{\mathrm{a}} \pm 0,65$ & $0,93^{\mathrm{a}} \pm 0,26$ & $3,42^{\mathrm{a}} \pm 1,47$ & $0,52^{b} \pm 0,16$ & $0,33^{\mathrm{a}} \pm 0,14$ \\
\hline 2 & $14,73^{b} \pm 1,63$ & $0,98^{\mathrm{b}} \pm 0,13$ & $0,76^{\mathrm{b}} \pm 0,34$ & $2,02^{b} \pm 0,72$ & $0,69^{\mathrm{a}} \pm 0,46$ & $0,26^{b} \pm 0,10$ \\
\hline 3 & $87,62^{\mathrm{c}} \pm 4,55$ & $1,06^{\mathrm{b}} \pm 0,20$ & $0,77^{\mathrm{b}} \pm 0,11$ & $0,56^{\mathrm{c}} \pm 0,08$ & $0,55^{b} \pm 0,28$ & $0,36^{\mathrm{a}} \pm 0,22$ \\
\hline Combination (C) & NS & NS & $* * *$ & $*$ & NS & $* * *$ \\
\hline A & $37,55^{\mathrm{a}} \pm 35,49$ & $1,23^{\mathrm{a}} \pm 0,46$ & $1,02^{\mathrm{a}} \pm 0,26$ & $2,72^{\mathrm{a}} \pm 1,19$ & $0,57^{\mathrm{a}} \pm 0,32$ & $0,29^{\mathrm{bc}} \pm 0,19$ \\
\hline $\mathrm{B}$ & $38,11^{\mathrm{a}} \pm 36,80$ & $1,42^{\mathrm{a}} \pm 0,59$ & $0,76^{\mathrm{bc}} \pm 0,16$ & $2,66^{\mathrm{a}} \pm 1,95$ & $0,55^{\mathrm{a}} \pm 028$ & $0,26^{\mathrm{c}} \pm 0,19$ \\
\hline $\mathrm{D}$ & $38,31^{\mathrm{a}} \pm 35,42$ & $1,28^{\mathrm{a}} \pm 0,40$ & $0,90^{\mathrm{ab}} \pm 0,37$ & $1,50^{\mathrm{bc}} \pm 0,93$ & $0,61^{\mathrm{a}} \pm 0,36$ & $0,38^{\mathrm{ab}} \pm 0,18$ \\
\hline $\mathrm{E}$ & $38,55^{\mathrm{a}} \pm 34,83$ & $1,48^{\mathrm{a}} \pm 1,07$ & $0,88^{\mathrm{ab}} \pm 0,34$ & $1,11^{\mathrm{c}} \pm 0,48$ & $0,71^{\mathrm{a}} \pm 0,43$ & $0,45^{\mathrm{a}} \pm 0,16$ \\
\hline $\mathrm{F}$ & $39,19^{\mathrm{a}} \pm 36,38$ & $1,32^{\mathrm{a}} \pm 0,52$ & $0,68^{\mathrm{c}} \pm 0,15$ & $1,99^{\mathrm{abc}} \pm 1,49$ & $0,56^{\mathrm{a}} \pm 0,29$ & $0,27^{\mathrm{c}} \pm 0,12$ \\
\hline $\mathrm{G}$ & $38,89^{\mathrm{a}} \pm 36,58$ & $1,34^{\mathrm{a}} \pm 0,51$ & $0,69^{\mathrm{c}} \pm 0,13$ & $2,06^{\mathrm{abc}} \pm 1,61$ & $0,53^{\mathrm{a}} \pm 0,25$ & $0,27^{\mathrm{c}} \pm 0,16$ \\
\hline $\mathrm{H}$ & $38,90^{\mathrm{a}} \pm 36,60$ & $1,41^{\mathrm{a}} \pm 0,64$ & $0,71^{\mathrm{c}} \pm 0,15$ & $1,86^{\mathrm{abc}} \pm 1,34$ & $0,55^{\mathrm{a}} \pm 0,26$ & $0,31^{b c} \pm 0,15$ \\
\hline $\mathrm{Y} \times \mathrm{H}$ & $* *$ & $* * *$ & $* * *$ & NS & $* * *$ & $* * *$ \\
\hline $\mathrm{Y} \times \mathrm{S}$ & $* * *$ & $* * *$ & $* * *$ & $* * *$ & $* * *$ & $* * *$ \\
\hline $\mathrm{Y} \times \mathrm{C}$ & $* * *$ & $* * *$ & $* * *$ & $* * *$ & $* * *$ & $* * *$ \\
\hline $\mathrm{H} \times \mathrm{S}$ & $* * *$ & $* * *$ & $* * *$ & $* * *$ & $* * *$ & $* * *$ \\
\hline $\mathrm{H} \times \mathrm{C}$ & $* * *$ & $* * *$ & $* * *$ & $* * *$ & NS & $* * *$ \\
\hline $\mathrm{S} \times \mathrm{C}$ & $* * *$ & $* * *$ & $* * *$ & $* * *$ & $* * *$ & NS \\
\hline $\mathrm{Y} \times \mathrm{H} \times \mathrm{S}$ & $* * *$ & $* * *$ & $* * *$ & $\mathrm{NS}$ & $* * *$ & $* * *$ \\
\hline $\mathrm{Y} \times \mathrm{H} \times \mathrm{C}$ & $* * *$ & $* * *$ & $* * *$ & $* * *$ & NS & $* * *$ \\
\hline $\mathrm{Y} \times \mathrm{S} \times \mathrm{C}$ & $* * *$ & $* * *$ & $* * *$ & $* * *$ & $* * *$ & $* * *$ \\
\hline $\mathrm{H} \times \mathrm{S} \times \mathrm{C}$ & $* * *$ & $* * *$ & $* * *$ & $* * *$ & $* * *$ & $* * *$ \\
\hline
\end{tabular}

In the course of the investigation, the amount of potassium dropped during sampling, while the lowest value was found in the fertilizing mix $\mathrm{E}(1,11 \%)$. The highest level was found in the fertilizing mix A (2,72\%). However, between the highest value of potassium in the combination $\mathrm{A}$ and values of the combinations $\mathrm{B}, \mathrm{C}, \mathrm{F}, \mathrm{G}$ and $\mathrm{H}$ there are not major differences. The only significant difference in calcium levels in the plant mineral composition was found during plant sampling. The other parameters monitored did not show major differences, although the highest value was found in the combination $\mathrm{E}(0,71 \%)$ where the com hybrids were treated with organic only fertilizer (MBM) in the maximum dosage.

As well as the aforementioned parameters of the plant mineral composition, the amount of magnesium considerably differs by investigation years and material samplings. A higher value was found in the first investigation year $(0,36 \%)$ and in the third sampling $(0,36 \%)$. As the calcium level, the highest level of magnesium $(0,45 \%)$ was found in the fertilizing mix E. Due to this, it can be determined that treatment with the maximum dosage of organic fertilizer had a positive effect on mineral composition of the plants, except for potassium, whose value was found to be by far the lowest.

\section{Conclusion}

Meat bone meal after anaerobic digestion treatment is possible to be applied as organic fertilizer. It has higher nutritive value and, as such, is suitable for treatment of agricultural plants, especially in crop production but there is no simple model that can be used to define the nutrient additions needed for corn. It is rich in biogenic elements, which makes them suitable for fertilizer in agricultural production. We can classify them in category of liquefied organic fertilizers with high amount of nitrogen, phosphorus, potassium, calcium, and magnesium and higher microelements content. Hence, this fertilizer can be used for fertilization but its application should be preceded by soil analysis and determination of needs of individual cultures for macro- and microelements. 


\section{References}

[1] Callaghan, F. J.; Wase, D.; Thayanity, K.; Forster. C. F. Co-digestion of waste rganic solids:batch studies. // Bioresource Technology. 67, 2(1999), pp. 117-122. DOI: 10.1016/S0960-8524(98)00108-4

[2] Callaghan, F. J.; Wase, D.; Thayanity, K.; Forster, C. F. Continuous co-digestion of cattle slurry with fruit and vegetable wastes and chicken manure. // Biomass Bioenergy. 22, (2002), pp. 71-77. DOI: 10.1016/09213449(90)90032-Y

[3] Arvanitoyannis, I. S.; Ladas, D. Meat waste treatment methods and potential uses. // International Journal of Food Science \& Technology. 43, 3(2008),pp. 543-559. DOI: 10.1111/j.1365-2621.2006.01492.x

[4] Garcia, R. A.; Rosentrater, K. A. Characteristics of North American meat and bone meal relevant to the development of non-feed applications. // Appl Eng Agric. 22, 5(2006), pp. 729-736. DOI: $10.13031 / 2013.21989$

[5] Deydier, E.; Guilet, R.; Sarda, R.; Sharrock, P. Physical and chemical characterization of crude meat and bone meal combustion residue: waste or raw material? // J Hazard Mater. 121, (2005), pp. 141-148. DOI: 10.1016/j.jhazmat.2005.02.003

[6] Rodehutscord, M.; Abel, H. J.; Friedt, W.; Wenk, C.; Flachowsky, G.; Ahlgrimm, H. J.; Johnke, B.; Kuhl, R.; Breves, G. Consequences of the ban of by-products from terrestrial animals in livestock feeding in Germany and the European union: altematives, nutrient and energy cycles, plant production, and economic aspects. // Arch Anim Nutr. 56, 2(2002), pp. 67-91. DOI: 10.1080/00039420214180

[7] Thiry, E. S. C.; Xambeu, L.; Penders, J. Current status of transmissible spongiform encephalopathies in ruminants. // BASE. 8, 4(2004), pp. 221-228.

[8] 1069/2009/EC. Laying down health rules as regards animal by-products and derived products not intended for human consumption and repealing Regulation (EC) No 1774/2002, 2009.

[9] Hogg, R. Mixing and Segregation in Powders: Evaluation, Mechanisms and Processes. // KONA Powder and Particle Journal. 27, (2009), pp. 3-17. DOI: 10.14356/kona.2009005

[10] Krolczyk, J. B. An attempt to predict quality changes in a ten-component granular system. // Technical Gazette. 21, 2(2014), pp. 255-261.

[11] Krolczyk, J. B. The use of cluster analysis method to describe the mixing process of the multi-element granular mixture. // Transactions of FAMENA. 38, 4(2014), pp. 4354.

[12] DIN EN 12506:2003.2003. Characterization of waste Analysis of eluates - Determination of $\mathrm{pH}$.

[13] ISO 7888:1985. Water quality - Determination of electrical conductivity, 1985.

[14] ISO 1871:1975. General directions for the determination nitrogen by the Kjeldahl method, 1975.

[15] USDA-SCS-NSCS. Soil survey laboratory methods manual, Soil survey investigations report No. 42, Version 2.0, 1992 .

[16] ISO 10390:2005. Soil quality - Determination of pH, 2005.

[17] SAS Institute, Inc. SAS User's Guide: Statisties. SAS Institute, Cary, NC, 2000

[18] Marchaim, U.; Criden, J. In: (D. L. Wise, ea.) Fuel gas production from biomass (1981) 1, CRC press, Boca Raton, FL., pp. 95-120.

[19] Shih, J. C. H. Recent development in poultry waste digestion and feather utilisation - a review. // Poultry Sci. 72, (1993), pp. 1617-1620. DOI: 10.3382/ps.0721617

[20] Salminen, E.; Rintala, J.; Lokshina, L. Y.; Vavilin, V. A. Anaerobic batch degradation of solid poultry slaughterhouse waste. // Water Sci Technoi. 41, (2000), pp. 33-41.
[21] Salminen, E.; Rintala, J. Anaerobic digestion of organic solid poultry slaughterhouse waste- a review. // Bioresource Tech. 83, (2002), pp. 13-26. DOI: 10.1016/S09608524(01)00199-7

[22] Wu, G.; Healy, M. G.; Zhan, X. Effect of the solid content on anaerobic digestion of meat and bone meal. // Bioresource Tech. 100, (2009), pp. 4326-4331. DOI: 10.1016/j.biortech.2009.04.007

[23] Official Gazette 91/2001. Regulation on ecological production in plant cultivation and plant products.

[24] Official Gazette 15/1992. Regulation on protection of agricultural land against harmful pollution agents.

\section{Authors' addresses}

\author{
Assistant Professor Sanja Kalambura Ph.D. \\ Corresponding author: \\ University of Applied Sciences Velika Gorica, \\ Zagrebačka 5, 10410 Velika Gorica, Croatia \\ Phone: +385915107400 \\ Fax: +38518976457 \\ E-mail: sanja.kalambura@vvg.hr
}

Full. Prof. Tajana Krička Ph.D.

Faculty of Agriculture, University of Zagreb, Svetošimunska 25, 10000 Zagreb, Croatia

Phone: +38512393777

Fax: +38512315300

Full. Prof. Darko Kiš Ph.D.

Full. Prof. Sonja Marić Ph.D.

Assistant Sunčica Guberac

Faculty of Agriculture,

J. J. Strossmayer University of Osijek,

Kralja Petra Svačića 1d, 31000 Osijek, Croatia

Phone: +38532343425

Fax: +385 31554853

E-mail: darko.kis@pfos.hr

E-mail: suncica.guberac@pfos.hr

Full. Prof. Dražan Kozak, Ph.D.

Full. Prof. Antun Stoić, Ph.D.

Mechanical Engineering Faculty in Slavonski Brod,

J. J. Strossmayer University of Osijek,

Trg Ivane Brlic Mazuranic 2,

35000 Slavonski Brod, Croatia

Phone: +38535446188

Fax: +385 35446446

E-mail: dkozak@sfsb.hr

E-mail: astoic@sfsb.hr

Aleksandar Racz, Ph.D.

University of Applied Health Sciences

Miramarska 38, 10000 Zagreb, Croatia

E-mail: aleksandar.racz@zvu.hr 